\title{
Article
}

\section{Raynaud's phenomenon}

Nuttall, Dilyse

Available at http://clok.uclan.ac.uk/19485/

Nuttall, Dilyse ORCID: 0000-0002-0561-5229 (2017) Raynaud's phenomenon. Nurse Prescribing, 15 (8). p. 376. ISSN 2052-2924

It is advisable to refer to the publisher's version if you intend to cite from the work.

10.12968/npre.2017.15.8.376

For more information about UCLan's research in this area go to

http://www.uclan.ac.uk/researchgroups/ and search for < name of research Group>.

For information about Research generally at UCLan please go to http://www.uclan.ac.uk/research/

All outputs in CLoK are protected by Intellectual Property Rights law, including Copyright law. Copyright, IPR and Moral Rights for the works on this site are retained by the individual authors and/or other copyright owners. Terms and conditions for use of this material are defined in the policies page.

\section{CLoK}

Central Lancashire online Knowledge www.clok.uclan.ac.uk

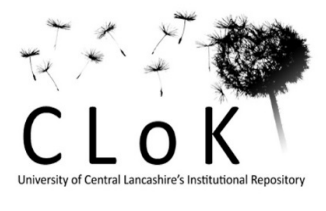




\section{Calculation Skills: Raynaud's Phenomenon}

Raynaud's phenomenon is a condition caused by vasospasm of the arteries which blocks the blood flow to the extremities, usually the fingers and/or toes but may also affect the ears, nipples, lips and nose (NICE, 2014). The condition can be triggered by stress, anxiety and cold temperatures (NHS Choices, 2015). Primary Raynaud's refers to the condition which develops without any underlying cause, whilst secondary Raynaud's is mainly caused by an underlying connective tissue disorder (NICE, 2014). Patient's with Raynaud's present with colour changes to the affected area (white, then blue, then red), often along with pain, numbness and pins and needles (NHS Choices, 2015).

\section{Question 1}

The prevalence of Raynaud's phenomenon is said to be between 3\% and 21\% (Carpentier, 2006). Based on these figures:

(i) What is the mean percentage of people affected by Raynaud's?

(ii) How many people in 1500 would be affected based on the lowest estimated percentage?

(iii) How many people in 1500 would be affected based on the highest estimated percentage?

\section{Question 2}

Judy is a 39 year old social worker. After making the recommended lifestyle changes, she has not seen any improvement in her condition and is to be prescribed prophylactic immediate-release nifedipine. She is required to start with the lowest recommended dose of $5 \mathrm{mg}$ (JFC, 2017), three times daily. $5 \mathrm{mg}$ capsules are available at a cost of $£ 5.73$ for 90 capsules.

(i) How many capsules will Judy need for the 16 days treatment until her next appointment?

(ii) What will be the cost of this period of treatment (based on price per tablet rounded up or down to nearest pence)

\section{Question 3}

Due to limited response to her initial treatment, Judy's nifedipine is increased in the weeks following her review appointment. She takes $10 \mathrm{mg} 3$ times daily for 14 days, $15 \mathrm{mg} 3$ times daily for 14 days and has been taking $20 \mathrm{mg} 3$ times daily for the last 7 days. Capsules are available in $5 \mathrm{mg}, 10 \mathrm{mg}$, and 20mg strengths.

(i) How much nifedipine in total (in grams) has Judy taken since commencing the treatment with nifedipine?

(ii) Assuming Judy took her nifedipine using the minimum number of capsules required to make up the dose, how many nifedipine capsules has she taken in total? 
Question 4

After a period of remission, Kim (a 29 year old writer) has presented again with Raynaud's. Due to suffering adverse effects from the immediate release nifedipine previously, she is to be prescribed modified-release off-label. She commences on the lowest recommended dose of $20 \mathrm{mg}$ modifiedrelease nifedipine once daily. $20 \mathrm{mg}$ capsules are available at a cost of $£ 5.41$ for 60 capsules.

What would be the difference in cost between seven days treatment with the lowest daily dose of modified-release nifedipine and the lowest daily dose of immediate-release nifedipine? (Based on price per tablet)

\section{Question 5}

Nice (2014) advise that up to two thirds of patients being treated with nifedipine suffer adverse effects. Based on your answer to question 1 (ii), how many of those patients will suffer adverse effects from nifedipine?

\section{Answers}

Question 1

(i) Mean percentage $=(3 \%+21 \%) \div 2=12 \%$

(ii) Number of people in 1500 that would be affected based on the lowest estimated percentage: $3 \%$ of 1500

$1 \%=1500 \div 100=15$

$3 \%=3 \times 15=45$

(iii) Number of people affected based on the highest estimated percentage: $21 \%$ of 1500 $21 \times 15=315$

Question 2

(i) $\quad$ Capsules required $=1$ (capsule) $\times 3$ (daily) $\times 16$ (days) $=48$

(ii) $\quad$ Cost per capsule $=f 5.73 \div 90=6 p$ (rounded down)

Cost per 16 days $=6 p \times 48=£ 2.88$

\section{Question 3}

Due to limited response to her initial treatment, Judy's nifedipine is increased in the weeks following her review appointment. She takes $10 \mathrm{mg}$ three for 14 days, $15 \mathrm{mg}$ for 14 days and has been taking 20 $\mathrm{mg}$ for the last 7 days. Capsules are available in $5 \mathrm{mg}, 10 \mathrm{mg}$, and $20 \mathrm{mg}$ strengths.

(i) First 16 days $=48 \times 5=240 \mathrm{mg}$

Next 14 days $=42 \times 10=420 \mathrm{mg}$

Next 14 days $=42 \times 15=630 \mathrm{mg}$

Last 7 days $=21 \times 20=420 \mathrm{mg}$ 


$$
\text { Total }=240+420+630+420=1710 \mathrm{mg} / 1.710 \mathrm{~g}
$$

(ii) First 16 days $=48$

Next 14 days $=42$

Next 14 days $=42$

Last 7 days $=21$

Total $=48+42+84+21=195$ capsules

\section{Question 4}

Cost of modified-release capsules:

1 day's treatment $=£ 5.41 \div 60=9 p($ rounded down $)$

7 day's treatment $=7 \times 9 p=63 p$

Cost of immediate-release capsules:

1 day's treatment $=3 \times 6 p=18 p$

7 day's treatment $=7 \times 18 p=£ 1.26$

Difference in cost $=£ 1.26-63 p=63 p$

\section{Question 5}

Nice (2014) advise that up to two thirds of patients being treated with nifedipine suffer adverse effects. Based on your answer to question 1 (ii), how many of those patients will suffer adverse effects from nifedipine?

Total people $=45$

$2 / 3 r d s=30$

\section{References}

Carpentier, P.H., Satger, B., Poensin, D. and Maricq, H.R. (2006) Incidence and natural history of Raynaud phenomenon: a long-term follow-up (14 years) of a random sample from the general population. Journal of Vascular Surgery, 44(5):1023-1028

Joint Formulary Committee (2017) BNF 73, London: JFC

NICE (2014) Raynaud's phenomenon, Clinical Knowledge Summaries, Available online at: https://cks.nice.org.uk/raynauds-phenomenon\#!background

NHS Choices (2015) Raynaud's phenomenon, NHS Choices, Available online at:

http://www.nhs.uk/conditions/Raynauds-phenomenon/Pages/Introduction.aspx 